\title{
In the differential diagnosis of wheezy infant, Chilaiditi syndrome caused by empty bottle absorption
}

\section{Hışıltılı çocuğun ayırıcı tanısında, boş biberon emmenin neden olduğu Chilaiditi sendromu}

\author{
illknur Bostancı, ${ }^{\oplus} \odot$ Çiğdem Üner, ${ }^{2} \odot$ Derya Erdoğan ${ }^{3}$ \\ 'Department of Pediatric Allergy and Immunology, Health Sciences University, Dr. Sami Ulus Maternity and Children Research and \\ Training Hospital, Ankara, Turkey \\ 2Department of Pediatric Surgery, Health Sciences University, Dr. Sami Ulus Maternity and Children Research and Training Hospital, \\ Ankara, Turkey \\ ${ }^{3}$ Department of Radiology, Health Sciences University, Dr. Sami Ulus Maternity and Children Research and Training Hospital, \\ Ankara, Turkey
}

\begin{abstract}
Chilaiditi syndrome is defined as hepatodiaphragmatic interposition of colon or small intestine. Wheezy infant and Chilaiditi syndrome are not described in the literature. Radiographs of the lung taken for differential diagnosis should be fully evaluated. We emphasize the importance of air under the right diaphragm in the wheezy infant. Keywords: Baby bottle; Chilaiditi syndrome; Wheezy infant.
\end{abstract}

T here are congenital or acquired diseases in the differential diagnosis of wheezy infant. ${ }^{[1]}$ The prevalence of early childhood wheeze varies considerably across Europe. Lower respiratory tract infections, day care attendance, postnatal smoke exposure and male gender are important risk factors. Infant wheezing is a very common condition during the first years of life and may develop into asthma if the condition is recurrent and severe. Chilaiditi's sign entity was first described by Demetrius Chilaiditi in 1910. Chilaiditi's sign is defined as colon or small intestine interposition between liver and diaphragm. When this sign is associated with gastrointestinal symptoms, this entity is known as Chilaiditi syndrome. The treatment of Chilaiditi syndrome is usually nonsurgical and includes bed rest, fluid supplementation, nasogastric decompression, enemas, cathartics, a high-fiber diet, and stool softeners.

\section{Özet}

Chilaiditi sendromu, kolon veya ince bağırsakta hepatodiafragmatik interpozisyon olarak tanımlanır. Wheezy infant ve Chilaiditi sendromu literatürde tariff edilmemiştir. Ayırıcı tanı için alınan akciğer grafileri tam olarak değerlendirilmelidir. Hışıltıtlı çocuklarda sağ diyafram altındaki havanın önemini vurguluyoruz.

Anahtar Sözcükler: Biberon; Chilaiditi sendromu; çocuk; hışıltı.

\section{Case Report}

A 1.5-year-old girl was admitted for bronchiolitis 1 time and otitis media 3 times in the last 6 months. In her history, there was not any other special feature, except she was receivingcontinuous infusion of empty bottles (Fig. 1). Our patient had no gastrointestinal findings. Physical examination revealed an adenoid face and wheezing. A plain chest $\mathrm{x}$-ray revealed a colon on the right side of the liver (Fig. 2). Ultrasound examination revealed a normal liver. Parents were informed about the condition. She was followed up without any complications in the clinic. Feeding bottle was stopped. Symptoms disappeared at 3-month follow-up.

\section{Discussion}

Chilaiditi sign refers to the asymptomatic interposition of

Corresponding (illetişim): Illknur Bostancı, Sağlık Bilimleri Üniversitesi, Dr. Sami Ulus Kadın Doğum ve Çocuk Hastanesi Eğitim ve Araştırma Hastanesi, Çocuk Allerji ve İmmünoloji Kliniği, Ankara, Turkey

E-mail (E-posta): ilknurbirol@hotmail.com

Received (Geliş Tarihi): 16.04.2019 Accepted (Kabul Tarihi): 26.08.2019 


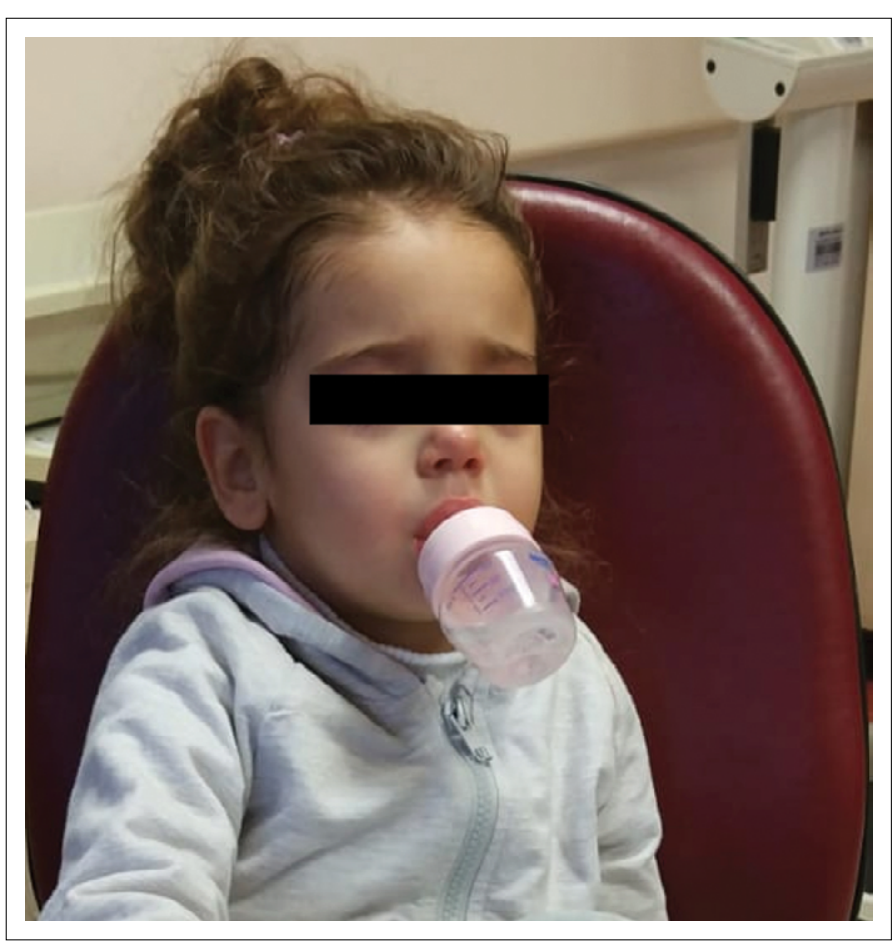

Figure 1. Photo of girl patient sucking empty bottle.

bowel between the liver and the diaphragm. Infants are more susceptible to develop wheezing because their airways are small, requiring less obstruction to produce an audible wheeze. ${ }^{[1,2]}$ The differential diagnosis of wheezing is quite extensive; therefore, a careful history and physical exam is warranted prior to beginning a workup directed towards the most likely diagnos. ${ }^{[3]}$ Colonic tension seen in chilaiditi syndrome caused by air aeration (aerophagia) is shown as one of the most important causes in children. ${ }^{[4,5]}$ Although Chilaiditi syndrome is benign and usually managed conservatively, it has a broad differential diagnosis including conditions which require urgent surgical intervention such as volvulus and bowel obstruction or ischaemia. The Chilaiditi sign may be confused for free subdiaphragmatic gas caused by perforated viscus. ${ }^{[6]}$ Our case was a normally developed, girl, but during sleep she was sucking empty bottles. We want to emphasize that sleep habits can harm the child.

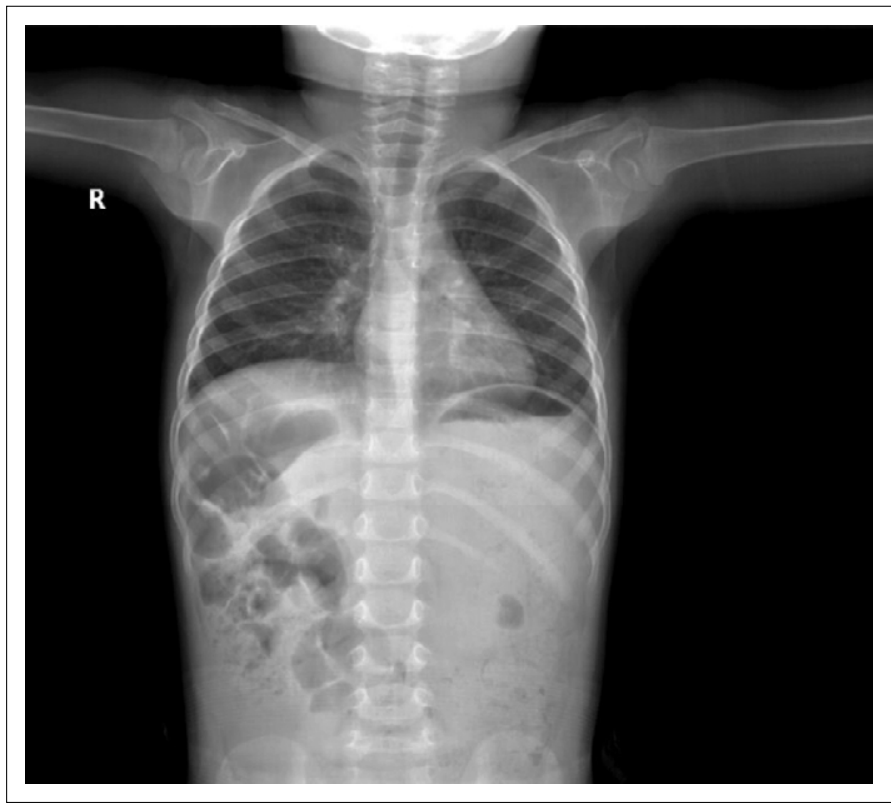

Figure 2. Chest radiograph demonstrating the Chilaiditi sign: elevated right hemidiaphragm, hepatodiaphragmatic interposition of an airdistended large bowel loop.

Conflict of interest: There are no relevant conflicts of interest to disclose.

\section{References}

1. Muglia C, Oppenheimer J. Wheezing in Infancy: An Overview of RecentLiterature.CurrAllergyAsthmaRep. 2017, 11;17(10):67

2. Evrengül H, Yüksel S, Orpak S, Özhan B, Ağladıoğlu K. ChilaiditiSyndrome. J Pediatr. 2016;173:260

3. Erdem SB, Nacaroğlu HT, Karkıner CŞÜ, Alper H, Can D. Chilaiditi Syndrome in Two Cases Presented with Respiratory Distress Symptoms. Turk Thorac J. 2015;16(2):97-100

4. Williams H. On theedge of the film... Chilaiditi'ssign. ArchDis Child EducPract Ed. 2014;99(1):15-6, 41

5. Pité H, Gaspar Â, Morais-Almeida M. Preschool-agewheezingphenotypesand asthma persistence in adolescents.Allergy Asthma Proc. 2016;37(3):231-41

6. Tan TS, Tan JS Chilaiditi syndrome: an uncommon cause of dyspnoea. Br J Hosp Med (Lond). 2019 2;80 (1):55. 